\title{
Ingestion of nylon threads by Gerreidae while using a tropical estuary as foraging grounds
}

\author{
Jonas A. A. Ramos ${ }^{1,2,3}$, Mário Barletta ${ }^{2,3, *}$, Monica F. Costa ${ }^{2,3}$ \\ ${ }^{1}$ Instituto Federal de Educação, Ciência e Tecnologia da Paraíba (IFPB), Campus Cabedelo, Paraíba, CEP 58310-000, Brazil \\ ${ }^{2}$ Laboratório de Ecologia e Gerenciamento de Ecossistemas Costeiros e Estuarinos, Dept. Oceanografia, UFPE, \\ Cidade Universitária, Recife, Pernambuco, CEP 50740-550, Brazil \\ ${ }^{3}$ Instituto de Ecologia e Gerenciamento de Ecossistemas Costeiros e Estuarinos (IEGEA), PO BOX 8132, Recife, Pernambuco, \\ CEP 51020-970, Brazil
}

\begin{abstract}
The ingestion of plastic fragments by 3 species of Gerreidae (Eugerres brasilianus, Eucinostomus melanopterus and Diapterus rhombeus) in a tropical estuary in Northeast Brazil was assessed for 3 different size classes corresponding to juveniles, sub-adults and adults. In all, 425 individuals were analysed. The gut contents of $13.4 \%$ of these individuals contained plastic debris. The only type of debris found was blue nylon fragments originating from ropes used in fishing. Artisanal fishing is the main local activity and was considered to represent the principal source of this marine debris. Significant differences in the number and weight of nylon fragments ingested were found between species and size classes. Moreover, a decrease in the weight of the gut contents was observed in the individuals that had ingested nylon fragments. In addition to the hypothesis that Gerreidae mistakenly identify nylon fragments as prey items, we propose 3 further possible pathways: (1) from fragments that the fishes' prey have already ingested; (2) through ingestion of fragments along with sediment that is sucked in during feeding; and (3) through ingestion of organisms that have aggregated on fragments.
\end{abstract}

KEY WORDS: Polyamide thread - Ontogenetic phase - Marine conservation · Plastic marine debris · Mojarra

Resale or republication not permitted without written consent of the publisher

\section{INTRODUCTION}

Plastics are a common type of marine pollution and are accumulating in the oceans (Carpenter et al. 1972, Thompson et al. 2004) and in coastal areas such as beaches, estuaries and mangroves (Santos et al. 2009, Costa et al. 2011, Ramos et al. 2011). In estuaries, small plastic fragments are easily transported due to the water movements in these ecosystems (Browne et al. 2010).

Tropical estuaries and their mangrove forests allow marine organisms to complete their life cycle by providing protection and feeding grounds (Krumme et al. 2005, Dantas et al. 2012b). The presence of plastic debris in these areas is a threat to animals such as marine turtles (Guebert-Bartholo et al. 2011) and fish
(Possatto et al. 2011, Dantas et al. 2012a), which risk ingestion of plastics or entanglement. Ingested plastics can reduce food uptake, and cause intestinal injuries and even the death of animals (Carpenter et al. 1972, Guebert-Bartholo et al. 2011).

The current knowledge of plastic ingestion by marine fish species has been documented and reviewed (Carpenter et al. 1972, Hoss \& Settle 1990, Possatto et al. 2011). Moreover, the occurrence of plastics in the stomach of fish species that spend their entire life cycle in estuaries, such as catfishes (Possatto et al. 2011) and drums (Dantas et al. 2012a), is reported at different ontogenetic phases. However, information about plastic ingestion by other fish species of ecological and economic importance in estuaries and coastal waters (e.g. species of the family Gerreidae) 
is lacking. Gerreidae are tropical marine fish frequently found in estuaries and mangrove forests (Cyrus \& Blaber 1982, Barletta \& Blaber 2007). In the Goiana estuary, Northeast Brazil, these fish provide income and food to the local communities (Barletta \& Costa 2009).

Possatto et al. (2011) and Dantas et al. (2012a) demonstrated that bottom-feeding fishes like Gerreidae from the Goiana estuary ingest microplastic fragments. The objective of this study was to investigate the ingestion of plastic debris by 3 size classes (juvenile, sub-adult and adult) of 3 gerreid species (Eugerres brasilianus, Eucinostomus melanopterus and Diapterus rhombeus) that use the Goiana estuary.

\section{MATERIALS AND METHODS}

Fish were sampled monthly from the main channel of the Goiana estuary, Northeast Brazil $\left(7^{\circ} 32^{\prime}\right.$ to $7^{\circ} 35^{\prime} \mathrm{S}, 34^{\circ} 54^{\prime}$ to $\left.34^{\circ} 58^{\prime} \mathrm{W}\right)$. Samples $(\mathrm{N}=234)$ were collected from January 2006 to March 2008 with an otter-trawl net (Dantas et al. 2010). In addition, 12 samples were collected in mangrove creeks from April to May 2008 (Ramos et al. 2011). The sampling nets were made of a type of material that differed from the type of plastic ingested by the fish.

The total length $\left(T_{\mathrm{L}}, \mathrm{cm}\right)$, total body weight $(W, \mathrm{~g})$ and weight without gonads $\left(W_{\mathrm{g}}, \mathrm{g}\right)$ of each individual were measured. The fish were assigned to different size classes (juvenile, sub-adult and adult) based on 2 criteria (Table 1). The first criterion, the inflection point of the length-weight curve, was used to distinguish the juveniles from sub-adults (Fig. A1 in Appendix 1). The second criterion, the length at first maturity $\left(L_{50}\right)$ was calculated (Lewis \& Fontoura 2005) and used to distinguish sub-adults from adults (Fig. A1). The plastic items found in stomachs of each individual were quantified according to their number, weight and frequency of occurrence. The condition factor $(K)$ was used to determine whether the presence of nylon fragments in the stomach can cause stress to the fish (e.g. weight loss). It was calculated according Richardson et al. (2011). However, body weight without gonads was used to remove maturation influence.

\section{Statistical analysis}

Data were Box-Cox transformed to improve the normality. A factorial ANOVA was used to compare the number and weight of plastic fragments for each size class and species and to compare the total weight of the gut contents and $K$ among individuals that had or not ingested plastic. In this analysis, Diapterus rhombeus was omitted because too few individuals were captured. If significant differences were detected by ANOVA, a Bonferroni test was used a posteriori to detect the source of the differences. Analyses were performed with STATISTICA version 8 (StatSoft) at a significance level of 0.05 .

\section{RESULTS}

A total of 425 fish were analysed, 240 of which were Eugerres brasilianus, 141 Eucinostomus melanopterus and 44 Diapterus rhombeus (Table 1). Approximately $13.4 \%$ (57 ind.) had ingested nylon

Table 1. Eugerres brasilianus, Eucinostomus melanopterus and Diapterus rhombeus. Size classes, number of individuals analysed, and number and frequency of individuals that ingested nylon fragments, mean weight of gut content $\left(W_{\mathrm{G}}\right)$ of individuals that ingested nylon, and mean $( \pm \mathrm{SE})$ weight of nylon $\left(W_{\mathrm{N}}\right)$, number of nylon fragments $\left(\mathrm{N}_{\mathrm{N}}\right)$ and fraction of gut content weight occupied by nylon $\left(\mathrm{F}_{\mathrm{G}}\right)$ for juveniles, sub-adults and adults. (-) No plastic contamination in stomach contents

\begin{tabular}{|c|c|c|c|c|c|c|c|c|c|}
\hline & \multirow[t]{2}{*}{ Stage } & \multirow{2}{*}{$\begin{array}{l}\text { Size class } \\
\quad(\mathrm{cm})\end{array}$} & \multirow{2}{*}{$\begin{array}{l}\text { Number } \\
\text { analysed }\end{array}$} & \multicolumn{2}{|c|}{ Fragment ingestion } & \multirow{2}{*}{$\begin{array}{c}W_{\mathrm{G}} \\
(\mathrm{mg})\end{array}$} & \multirow{2}{*}{$W_{\mathrm{N}}(\mathrm{mg})$} & \multicolumn{2}{|c|}{ Jylon ingestion } \\
\hline & & & & (no. ind.) & (\% of ind.) & & & $\mathrm{N}_{\mathrm{N}}(\mathrm{mg})$ & $\mathrm{F}_{\mathrm{G}}(\%)$ \\
\hline \multirow[t]{3}{*}{ E. brasilianus } & Juvenile & $<9$ & 141 & 18 & 12.8 & 80 & $0.02 \pm 0.01$ & $0.16 \pm 0.05$ & $0.58 \pm 0.19$ \\
\hline & Sub-adult & $9-13$ & 72 & 12 & 16.7 & 159 & $0.03 \pm 0.02$ & $0.18 \pm 0.06$ & $0.19 \pm 0.06$ \\
\hline & Adult & $>13$ & 27 & 9 & 33.4 & 689 & $0.11 \pm 0.03$ & $0.78 \pm 0.11$ & $0.15 \pm 0.05$ \\
\hline \multirow[t]{3}{*}{ E. melanopterus } & Juvenile & $<5$ & 41 & 2 & 4.9 & 7 & $0.01 \pm 0.02$ & $0.05 \pm 0.09$ & $5.38 \pm 3.71$ \\
\hline & Sub-adult & $5-7.5$ & 56 & 5 & 8.9 & 38 & $0.02 \pm 0.02$ & $0.14 \pm 0.07$ & $1.0 \pm 0.40$ \\
\hline & Adult & $>7.5$ & 44 & 6 & 13.6 & 313 & $0.04 \pm 0.02$ & $0.16 \pm 0.08$ & $0.19 \pm 0.08$ \\
\hline \multirow[t]{3}{*}{ D. rhombeus } & Juvenile & $<6$ & 4 & 0 & - & - & - & - & - \\
\hline & Sub-adult & $6-9.54$ & 7 & 1 & 14.3 & 193 & $0.04 \pm 0.05$ & $0.28 \pm 0.21$ & 0.15 \\
\hline & Adult & $>9.54$ & 33 & 4 & 12.1 & 354 & $0.08 \pm 0.03$ & $0.18 \pm 0.09$ & $0.24 \pm 0.19$ \\
\hline Total & & 425 & 57 & & & & & & \\
\hline
\end{tabular}


fragments. The nylon fragments were blue, and their length ranged from 1 to $5 \mathrm{~mm}$. The nylon debris originated from lines used in fishing activities. Ingestion ranged from 1 to 5 fragments per fish and was evident in the gut contents of the 3 size classes of the 3 species, with the exception of the juveniles of $D$. rhombeus (Table 1).

Number and weight of nylon fragments ingested differed significantly among species $\left(F_{1,375}=15.72\right.$, $\mathrm{p}=0.0009$, and $F_{1,375}=6.5031, \mathrm{p}=0.0112$, respectively), with the highest mean values, in number and weight, ingested by Eugerres brasilianus (Table 1). Differences between the size classes, in number and weight, were also detected $\left(F_{2,375}=9.97, \mathrm{p}=0.0001\right.$, and $F_{2,375}=6.5892, \mathrm{p}=0.0015$, respectively). The highest mean number and weight of plastic ingestion occurred in adults (Table 1). Moreover, for the number of nylon fragments, a significant species-size class interaction was detected $\left(F_{2,375}=6.49, \mathrm{p}=\right.$ 0.017 ). This result suggests that the number of nylon fragments ingested is influenced by the size class of each species (Table 1).

The ingested nylon fragments represented a small fraction of the gut contents weight of fish that had ingested nylon, and ranged from 0.15 to $5.38 \%$ (Table 1). Moreover, the occurrence of nylon fragments in the stomach in relation to the total weight of the gut contents for each size class showed a significant difference for adults of Eugerres brasilianus $\left(F_{2,369}=3.3324, \mathrm{p}=0.0368\right)$. The adults of this species that ingested nylon fragments showed lower mean total weight of gut contents than those that had not ingested nylon (Fig. 1). $K$ did not differ among species or size class for each species between individuals that ingested nylon and those that had not ingested nylon $\left(F_{2,375}=1.6441, \mathrm{p}=0.1945\right)$.

\section{DISCUSSION}

In the present study, $13.4 \%$ of the fish sampled were found to have nylon fragments in their stomachs. This result was similar to that of studies reporting plastic ingestion by fish as a significant form of pollution, e.g. species of the family Ariidae (23\%; Possatto et al. 2011) and Sciaenidae (7.9\%; Dantas et al. 2012a). The occurrence of blue nylon fragments in the gut contents of 3 gerreid species confirms these previous findings.

Artisanal and commercial fishing are strong and widely developed by the traditional communities around the Goiana estuary (Barletta \& Costa 2009). Fisheries can be responsible for the generation of a number of types of plastic marine debris, from large items such as nets, buoys and crates to microplastics such as paint chips (Turner et al. 2008) and nylon threads (Costa et al. 2011). The nylon fragments in the gut contents of Gerreidae species detected in this study can be classified as microplastics $(<5 \mathrm{~mm})$, which can easily be ingested by benthic and demersal fishes (Possatto et al. 2011, Dantas et al. 2012a). In this study, no significant differences were found in the condition factor of the gerreid species if nylon fragments were ingested. This result did not exclude the possiblity of physiological effects, since these effects are difficult to predict (Possatto et al. 2011). However, the reduction in the amount of natural food ingested if plastic ingestion occurs, as observed for adults of Eugerres brasilianus, could be an indication of these physiological effects, as predicted for fish (Carpenter et al. 1972) and sea turtles (GuebertBartholo et al. 2011).

Fish are known to ingest plastic marine debris of different shapes, sizes and densities (Hoss \& Settle
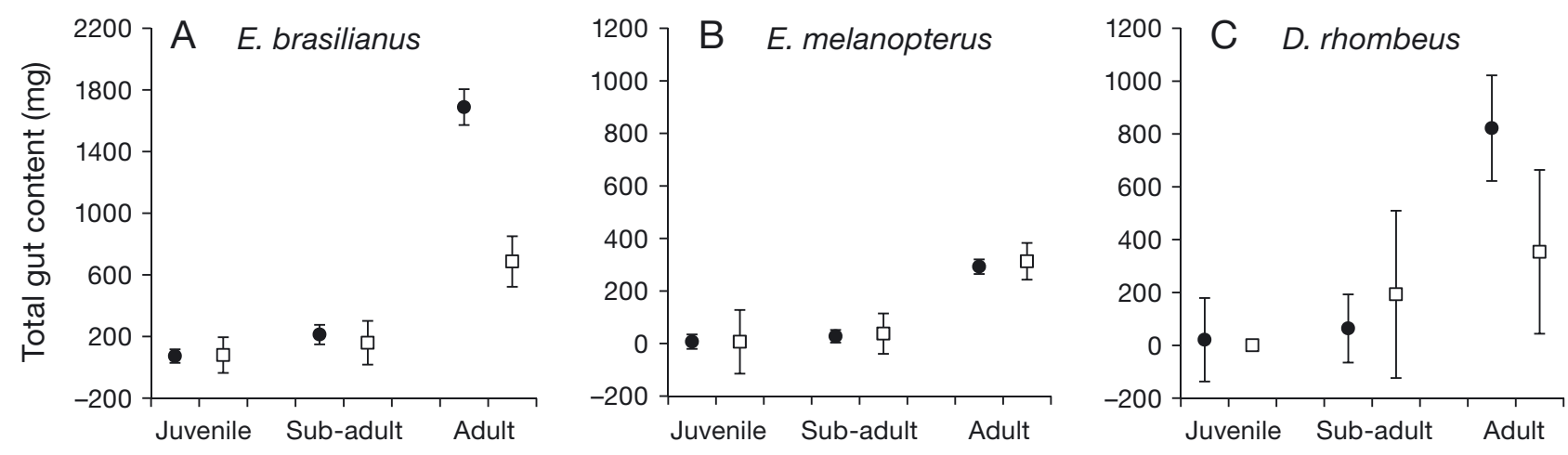

Fig. 1. Eugerres brasilianus, Eucinostomus melanopterus and Diapterus rhombeus. Mean ( \pm SE) total gut content weight of (A) E. brasilianus, (B) E. melanopterus and (C) D. rhombeus for fish that ingested nylon fragments (white squares) and fish that did not ingest nylon fragments (black circles). Data are presented by size class 
1990, Possatto et al. 2011). It was expected that other types of plastic would also be present in the stomach contents of the fish studied here due to their availability in estuarine sediments. Costa et al. (2011) sampled the sediment in the tidal plain of this estuary, where depositional conditions may differ from those in the habitats where fish were sampled for this study, and found other plastics $\left(\sim 47\right.$ items $\left.\mathrm{m}^{-3}\right)$ at a higher density than nylon fragments $\left(\sim 16\right.$ items $\left.\mathrm{m}^{-3}\right)$. However, only nylon threads were ingested. This result suggests that the gerreids examined might be selectively ingesting this type of plastic debris for a reason associated with feeding patterns, behaviour and prey preference.

Gerreidae are bottom feeders and obtain food items on or below the surface of the substratum (Cyrus \& Blaber 1982). They could show a selective preference for certain prey, such as bivalve siphons (Cyrus \& Blaber 1983). However, no published data indicate the possible preferences of these species for specific colour and/or shape. In the Goiana estuary, the species studied show an ontogenetic shift in diet, feeding in different proportions on the same types of prey (Ramos 2011). In this study, these ontogenetic differences were also noted for nylon ingestion.

It is probable that the ingestion of nylon fragments occurs in different ways. A common hypothesis is that fish ingest nylon during feeding if they incorrectly identify it as a potential prey item (e.g. small polychaetes) (Hoss \& Settle 1990, Possatto et al. 2011). We suggest that there are 3 other manners by which gerreids ingest nylon fragments. (1) The source of the fragments can be the marine food web because plastic fragments can be ingested by benthic fauna such as bivalves (Browne et al. 2008), amphipods, barnacles and polychaetes (Thompson et al. 2004), the preferred prey ingested by Gerreidae (Cyrus \& Blaber 1983, Teixeira \& Helmer 1997). (2) Gerreids have a protractile mouth and feed using suction pressure. When feeding, they usually suck in sediment surrounding the prey to maximise predation efficiency (Cyrus \& Blaber 1982). During this process, nylon fragments may be ingested, if available in the sediment (Costa et al. 2011). (3) Certain organisms (e.g. diatoms) can aggregate on the surfaces of plastic debris and construct a biofilm (Masó et al. 2003) that could be attractive to gerreids (Cyrus \& Blaber 1983). Furthermore, we emphasise that because gerreid species are also prey to other consumers at higher levels in estuarine and coastal food webs, plastic contamination might be transferred to these higher-level predators (Eriksson \& Burton 2003).
Plastic ingestion could result in intestinal damage, and transfer persistent organic pollutants to the fish. However, the effects of exposure to nylon fragments are still unknown. To obtain this information, a controlled experiment should be designed. The occurrence of plastic fragments in fish stomach contents also reflects the wide availability of this type of debris in this ecosystem. This study provides an important contribution to the understanding of problems associated with marine debris in estuarine environments. In addition, the results of this study can support mitigation efforts and control actions. Further studies on the contamination of other animal groups are needed to better understand how plastic pollution is affecting food webs.

Acknowledgements. The authors appreciate the financial support of the Conselho Nacional de Desenvolvimento Científico e Tecnológico (CNPq) (474736/2004, 482921/2007-2, CT-Hidro 552896/2007-1) and Fundação de Amparo à Ciência e Tecnologica de Pernambuco (FACEPE). J.A.A.R. thanks the CNPq for a Doctoral Scholarship. M.B. and M.F.C. are CNPq fellows. We also thank the 3 anonymous referees for their comments, which improved this manuscript.

\section{LITERATURE CITED}

Barletta M, Blaber SJM (2007) Comparison of fish assemblages and guilds in tropical habitats of the Embley (Indo-west Pacific) and Caeté (Western Atlantic) estuaries. Bull Mar Sci 80:647-680

Barletta M, Costa MF (2009) Living and non-living resources exploitation in a tropical semi-arid estuary. J Coast Res 56:371-375

Browne MA, Dissanayake A, Galloway TS, Lowe DM, Thompson RC (2008) Ingested microscopic plastic translocates to the circulatory system of the mussel, Mytilus edulis (L.). Environ Sci Technol 42:5026-5031

> Browne MA, Galloway TS, Thompson RC (2010) Spatial patterns of plastic debris along estuarine shorelines. Environ Sci Technol 44:3404-3409

Carpenter EJ, Anderson SJ, Harvey GR, Miklas HP, Peck BB (1972) Polystyrene spherules in coastal waters. Science 178:749-750

Costa MF, Silva-Cavalcanti JS, Barbosa CC, Barletta M (2011) Plastic buried in the inter-tidal plain of a tropical estuarine ecosystem. J Coast Res 64:339-343

Cyrus DP, Blaber SJM (1982) Species identification, distribution and abundance of Gerreidae (Teleostei) Bleeker, 1859 in the estuaries of Natal. S Afr J Zool 17:105-116

> Cyrus DP, Blaber SJM (1983) The food and feeding ecology of Gerreidae, Bleeker 1859, in the estuaries of Natal. J Fish Biol 22:373-393

> Dantas DV, Barletta M, Costa MF, Barbosa-Cintra SCT and others (2010) Movement patterns of catfishes (Ariidae) in a tropical semi-arid estuary. J Fish Biol 76:2540-2557

> Dantas DV, Barletta M, Costa MF (2012a) The seasonal and spatial patterns of ingestion of polyfilament nylon fragments by estuarine drums (Sciaenidae). Environ Sci Pollut Res 19:600-606

Dantas DV, Barletta M, Lima ARA, Ramos JAA, Costa MF, 
Saint-Paul U (2012b) Nursery habitat shifts in an estuarine ecosystem: patterns of use by sympatric catfish species. Estuar Coast 35:587-602

Eriksson C, Burton H (2003) Origins and biological accumulation of small plastic particles in fur seals from Macquarie Island. Ambio 32:380-384

Guebert-Bartholo FM, Barletta M, Costa MF, MonteiroFilho ELA (2011) Using gut contents to assess foraging patterns of juvenile green turtles Chelonia mydas in the Paranaguá Estuary, Brazil. Endang Species Res 13: 131-143

Hoss DE, Settle L (1990) Ingestion of plastics by teleost fishes. In: Shomura RS, Codfrey HL (eds) Proceedings of the Second International Conference on Marine Debris. US Department of Commerce, NOAA Technical Memorandum NMFS, Washington, DC, p 693-709

Krumme U, Keuthen H, Barletta M, Villwock W, Saint-Paul U (2005) Contribution to the feeding ecology of the predatory wingfin anchovy Pterengraulis atherinoides (L.) in north Brazilian mangrove creeks. J Appl Ichthyol 21:469-477

> Lewis DDS, Fontoura NF (2005) Maturity and growth of Paralonchurus brasiliensis females in southern Brazil (Teleostei, Perciformes, Sciaenidae). J Appl Ichthyology 21:94-100

Masó M, Garcés E, Pagès F, Camp J (2003) Drifting plastic debris as a potential vector for dispersing harmful algal bloom (HAB) species. Sci Mar 67:107-111
Possatto FE, Barletta M, Costa MF, Ivar do Sul JA, Dantas DV (2011) Plastic debris ingestion by marine catfish: an unexpected fisheries impact. Mar Pollut Bull 62: 1098-1102

Ramos JAA (2011) Ecologia alimentar e os hábitats utilizados por cada fase ontogenética das espécies pertencentes à família Gerreidae (Actinopterigii - Perciformes) no estuário do Rio Goiana (PE/PB). MSc dissertation, Universidade Federal de Pernambuco, Recife

Ramos JAA, Barletta M, Dantas DV, Lima ARA, Costa MF (2011) Influence of moon phase on fish assemblages in estuarine mangrove tidal creeks. J Fish Biol 78:344-354

Richardson N, Gordon AK, Muller WJ, Whitfield AK (2011) A weight-of-evidence approach to determine estuarine fish health using indicators from multiple levels of biological organization. Aquat Conserv 21:423-432

Santos IR, Friedrich AC, Ivar do Sul JA (2009) Marine debris contamination along undeveloped tropical beaches from northeast Brazil. Environ Monit Assess 148:455-462

Teixeira RL, Helmer JL (1997) Ecology of young mojarras (Pisces: Gerreidae) occupying the shallow waters of a tropical estuary. Rev Bras Biol 57:637-646

- Thompson RC, Olsen Y, Mitchell RP, Davis A and others (2004) Lost at sea: Where is all the plastic? Science 304: 838

Turner A, Fitzer S, Glegg GA (2008) Impacts of boat paint chips on the distribution and availability of copper in an English ria. Environ Pollut 151:176-181 


\section{Appendix 1}

E. brasilianus
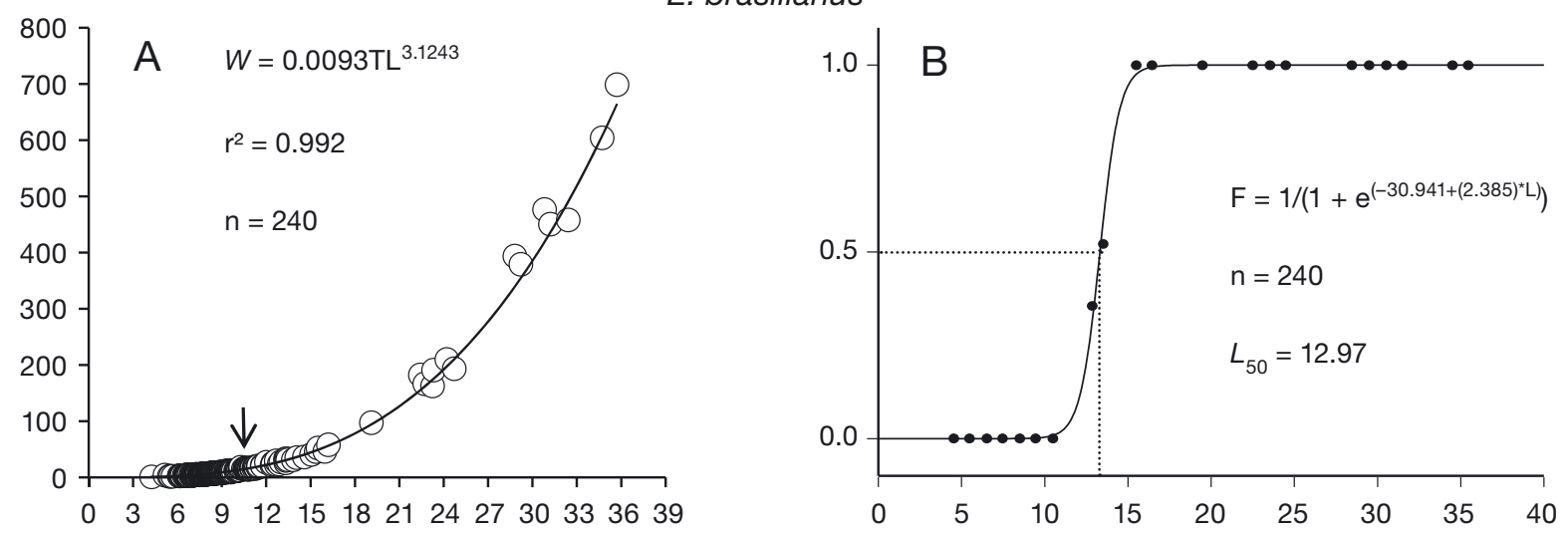

E. melanopterus
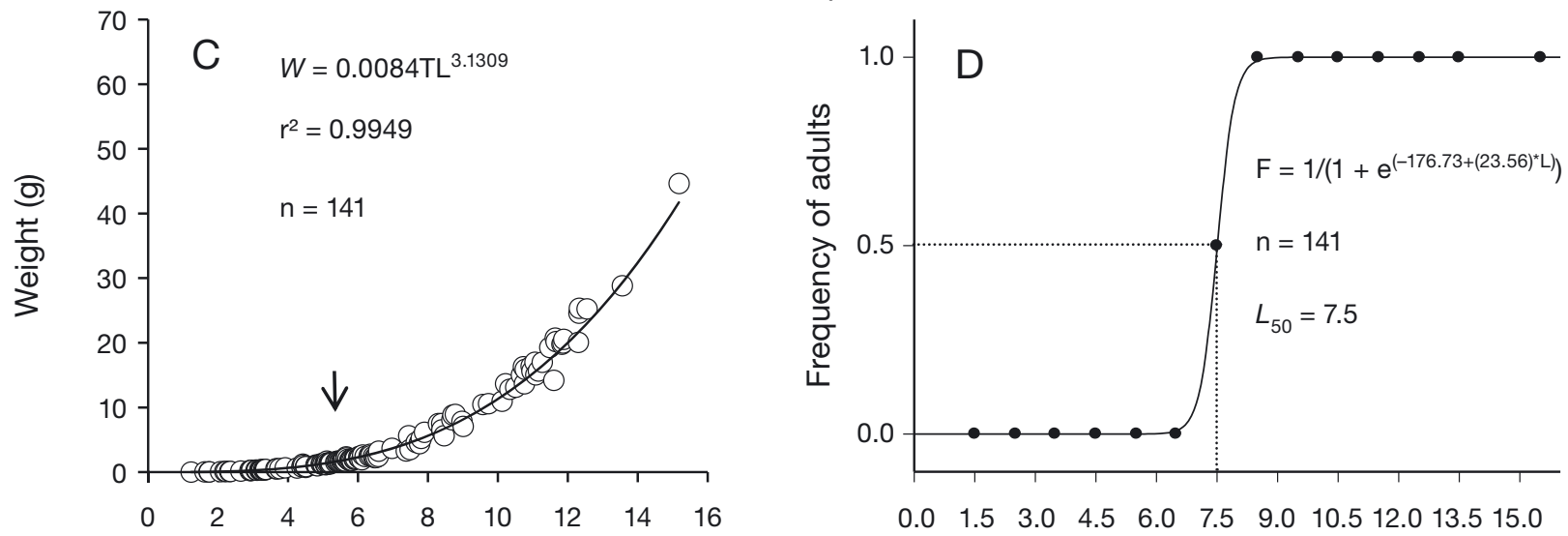

D. rhombeus
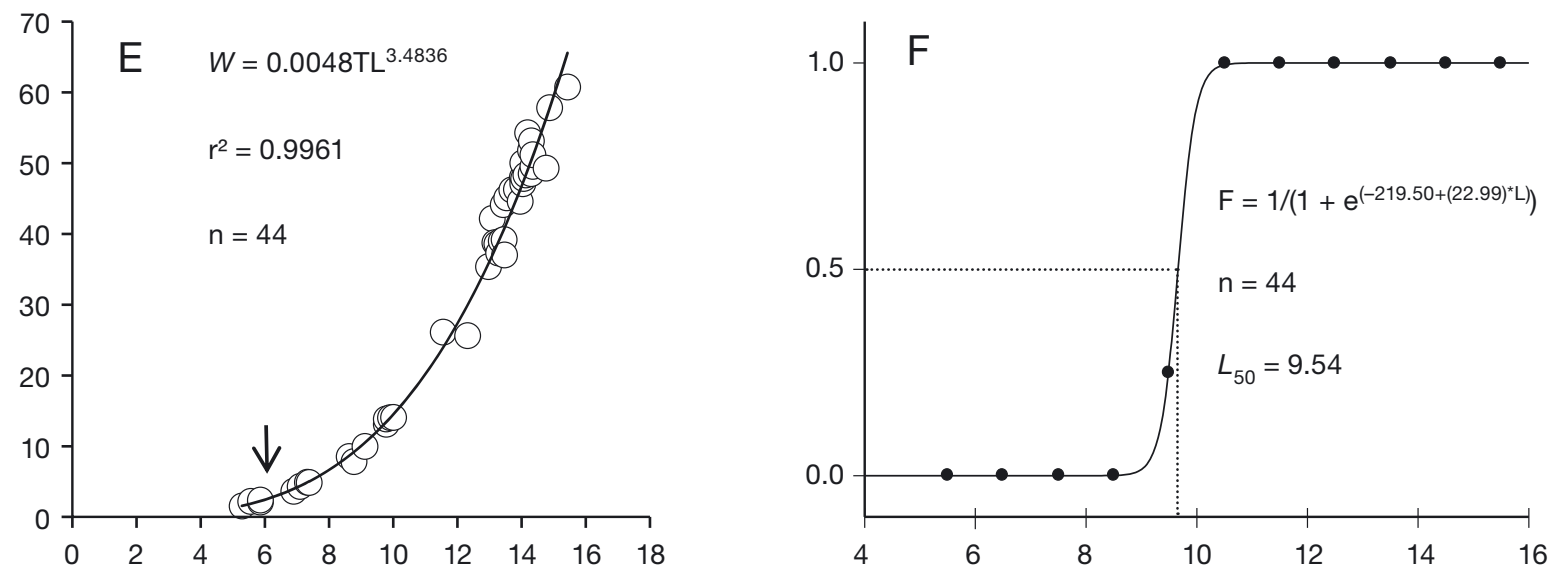

Total length $(\mathrm{cm})$

Fig. A1. Eugerres brasilianus, Eucinostomus melanopterus and Diapterus rhombeus. Length-weight relationship (arrows indicate size at inflection point) and relative frequency of adults (lines in maturation curve indicate length at first maturity $\left[L_{50}\right]$ ) of $(\mathrm{A}, \mathrm{B})$ E. brasilianus, $(\mathrm{C}, \mathrm{D})$ E. melanopterus and $(\mathrm{E}, \mathrm{F})$ D. rhombeus. W: weight $(\mathrm{g})$; F: frequency 